\section{SOI: $1.1 /$ TAS DOI: $10.15863 /$ TAS International Scientific Journal Theoretical \& Applied Science}

\author{
p-ISSN: 2308-4944 (print) e-ISSN: 2409-0085 (online) \\ Year: 2015 Issue: 07 Volume: 27
}

Published: $30.07 .2015 \quad$ http://T-Science.org

SECTION 29. Literature. Folklore. Translation Studies.
Ruziya Zaman Gulieva

Ph.D., teacher

Ganja Branch of ANAS, Ganja, Azerbaijan

E.M. Shirinova

teacher

Ganja Branch of ANAS, Ganja, Azerbaijan

S.S. Abdinova

teacher

Ganja Branch of ANAS, Ganja, Azerbaijan

1-hasan@mail.com

\title{
AZERBAIJANI FOLKLORE AND THE SACRED LAW
}

Abstract: In this paper have been investigated the main moments of Azerbaijani literature and folklore with comparison of the basic holy books as Bible. Also on the basis of new scientific arguments and facts were researched the basic characteristics of relations between ancient folklore materials of Azerbaijan and other nations during centuries.

Key words: Azerbaijani literature and folklore, Bible, sacred law.

Language: English

Citation: Gulieva RZ, Shirinova EM, Abdinova SS (2015) AZERBAIJANI FOLKLORE AND THE SACRED LAW. ISJ Theoretical \& Applied Science 07 (27): 101-103.

Soi: http://s-o-i.org/1.1/TAS-07-27-16 Doi: crossef http://dx.doi.org/10.15863/TAS.2015.07.27.16

Christian Old Testament features more than 24 books of the original Hebrew Bible, and deliberately in a divergent order. Moreover, there are a number of different versions of the Christian Bible, with different selections of books, as well as different ordering and naming of books, or incorporation of additional material into the books. The unifying property of the varying Christian Bibles is that all their books were originally written in Greek.

The hidden secrets of the heavens opening up the books is the role and importance of folklore. Therefore, both from the same divine source. One of the provisions by means of writing, and the other was transmitted orally from generation to generation. Glancing at the Holy Bible is clear that a large part of the illustrations are illustrations that guide the folk wisdom.

The Former Prophets are the books Joshua, Judges, Samuel and Kings. They contain narratives that begin immediately after the death of Moses with the divine appointment of Joshua as his successor, who then leads the people of Israel into the Promised Land, and end with the release from imprisonment of the last king of Judah. Treating Samuel and Kings as single books, they cover:

Joshua's conquest of the land of Canaan (in the Book of Joshua),

the struggle of the people to possess the land (in the Book of Judges),

the people's request to God to give them a king so that they can occupy the land in the face of their enemies (in the Books of Samuel) the possession of the land under the divinely appointed kings of the House of David, ending in conquest and foreign exile (Books of Kings).

That is the key. Therefore, simple illustrations that appear at the top of the inner meanings hidden in the downstairs floor of the attention should be paid more.

Here we come to the conclusion that the matters are kept secret from the origin of secrets hidden in modern times. In other words, sayings date coded memory of mankind. During the folklore parallels between the Holy Gospel it is known that a lot of similarities between the two sources. Because of the parables of Jesus Christ explains the mysteries of the kingdom of heaven. The reason for this is that the national laws of the universe through folklore is more easily understand and follow him.

As you know, the relationship between folklore and equal relations, and sometimes prefer it.

In Christian Bibles, the New Testament Gospels were derived from oral traditions in the second half of the first century CE. Riches says that:

Scholars have attempted to reconstruct something of the history of the oral traditions behind the Gospels, but the results have not been too encouraging. The period of transmission is short: less than 40 years passed between the death of Jesus and the writing of Mark's Gospel. This means that there was little time for oral traditions to assume fixed form. The Bible was later translated into Latin and other languages. John Riches states that: 
The translation of the Bible into Latin marks the beginning of a parting of the ways between Western Latin-speaking Christianity and Eastern Christianity, which spoke Greek, Syriac, Coptic, Ethiopic, and other languages.

The Bibles of the Eastern Churches vary considerably: the Ethiopic Orthodox canon includes 81 books and contains many apocalyptic texts, such as were found at Qumran and subsequently excluded from the Jewish canon. As a general rule, one can say that the Orthodox Churches generally follow the Septuagint in including more books in their Old Testaments than are in the Jewish canon.

The mythology of Azerbaijan is not of systematic and full character in comparison with that of the ancient India and the ancient Greek. But it is possible to find out the traces of Azerbaijan mythology in Azerbaijan folklore. They are generally the elements of cosmogonic, seasonal and ethnogonic myths. Those mythic elements, being the result of artistic thinking of primary formation of human society, reflect cosmos and chaos, i.e. mixture in world life, disorder, the creation of world life (order) off this irregularity and the reflection of all this in human society. Cosmos in mythic world-outlook, i.e. rules accepted by most of the people, reflects the process of mutual understanding between the major rule of the society- family, life, man and the nature. Separate details of mythological world-outlook are still remained in the texts concerning sorcery, cheers, curses, tales, godu and the ceremony of counting (sayachy) of the folklore.

The Bible is clear that both Turkic peoples, as well as the private rites of the ancient Jews to repent olunarmis out of which the most important thing was to sit in sackcloth and ashes.

The law is similar to many traditions of the Azerbaijani people. One of them is the tradition to give to charity. For the sake of God, who gives to charity and faith of the people. Others do if the charity does not accept the presence of God.

Certain periods of history, revealing a number of forgotten traditions and folklore of the comparative study of the heavenly books to tell the important scientific considerations. Hidden in the lower layers of the tongue and in the possession of traces of certain customs, rituals opens with the heavenly books.

The old Turkish mythological thinking is the leading motive In the majority of mythological texts. This could be seen cosmogonic myths concerning the creation of the world, as well as in ethnogonic myths concerning the origin of the ethnos and calendar myths concerning season processes.

The creation of the mythological texts and their preservation in the form of the elements in folklore texts is closely related with human attitude towards the nature and natural forces. Human desire to effect natural forces by word, movement and dance the provoked necessity to create mythological texts and perform them. For instance, ceremonial songs and dances such as "Kosa-Kosa", "Godu-Godu", "Novruz", "xidir Nabi" are of that kind.

By the way, more works of Azerbaijani writers, thinkers are the main sources in research of ancient folklore past of our nation. For example, Nizami Ganjavi, Mirza Shafi Vazeh, V. Khuluflu and etc. It is known that Vali Khuluflu has valuable services who is outstanding, intellectual, one of the active scientific-cultural patriots of $20-30^{\text {th }}$ years in folk-lore and ethnography activities performed by the Azerbaijan Research and Investigation Society. He was sent on excursion by the Society and preparing folk-lore samples on the basis of oral folk literature which collected from the excursion districts of Tovuz, Shamkir, Gazakh and published them in the form of books. The outstanding folklorist's first folklore collection is "El ashiqlari". "El ashiqlari" book was printed under the heading series of "The materials from folk literature of Azerbaijan" by "Khalqiyyat" department of Azerbaijan Research and Investigation Society in 1926. This includes poet samples from different performances of ashugs written by Vali Khuluflu and "Reyhan" epos belonging to Asiq Huseyn. There is compact biographic information about Gurbani, Dada Yadigar, Khasta Gasim, Ashiq Alasgar, Huseyn Shamkirli and other masters whose goshmas, garaylis, and tacnis in the book.

During the scientific excursion in $1925-26^{\text {th }}$ years in Tovuz his collection "Koroghlu gollari" from famous people craftsman Ashiq Huseyn Bozalganli was published in 1927 and 1929 in two different publication forms. First publication is Koroghlu text which was published in stamp of "Society of Learning Azerbaijan". This includes 2 "gols" "Togat visit" and "Baghdad visit".

In 1929 Vali Khuluflu who holds the new publication introduction of "Koroghlu", for this time he introduces the for "gols" of the epos-"Togat visit". "Baghdad visit", "Darband visit", and "Dali Koroghlu and Bolu bay" to his readers. We should note that, there is information about printing after collecting excellent text of "Koroghlu" epos by Khuluflu in sources. Learning this Armenians begin to find different ways to assimilate it. One Armenian folklorist Kananyan who lives in Iravan came to Baku and met with Khuluflu and promised him to give great surprises for publishing his Koroghlu epos as Armenian epos. But Khuluflu noted decisively that Koroghlu is Turkish epos and it is impossible to call it as Armenian epos. In 1937 Khuluflu was arrested, then was taken to Iravan with taking Koroghlu epos during investigation. The epos was translated into Russian in 1941 in Iravan as "Armenian version of Koroghlu". The Armenian version of the epos was appeared like this. The "Riddles book" published in 1948 is one of the 
successful result of collective and publication activity of Khuluflu. The work was performed by Azerbaijan Research and Investigation Society. Investigator-scientifist Aybaniz Knagrali note that it seems Khuluflu gives special importance to not only the said texts but also two main principals in publication , collecting of folklore samples, publication writing with possible variations of folklore samples; passport of the written material; describing the place and by whom of the text.

During working in responsible positions Vali Khuluflu he continued to his secret struggle in the direction of protection of national existence, upbringing in the national spirit of the people. That's why he published widely collecting the samples of oral folklore literature. He noted this idea over and over again. "Folklore is the blood memory of the nation". We must collect it, to transfer it to the future generations and protect the inheritance between past and future.

For this purpose he visited to Gazax, Tovuz, Goycha, Iravan, Ganja, Dashkasan, Gadabay, Kalbajar, Goranboy and nakhchivan in 1920-1930. he collected folklore samples among peoples and revealed ashiq plays of Ashiq Huseyn, Gurbani, Dada Yadigar, Khasta Gasim, Ashiq Alasgar, Ashiq Huseyn Bozalganli and others and published them in the book form. At the same time he published "Azerbaijan Folklore" book from oral folklore samples which he collected in different years. One of the biggest services of Khuluflu was collecting the folklore of Asikha Turks. As if he felt the misfortunes that happened to asikhas after years and their exile from native lands to Middle Asia and Kazakhstan. For this purpose he went to Georgia where ashikas lived and stayed with them for months and collected their folklore. After returning he published his collection samples in the book form. Today the folklore of Asikha turks who live in every part of CIS region was protected thanks to this great scientist. But we should note that Khulufly wasn't enough with only collecting folklore samples between asikhas, but also propagated the ideas of joining as fist, to participate from unique position and struggle against Bolsheviks and unity among the nations. The ideas analyzed above, apparently Khuluflu has valuable activity in forming of Azerbaijan folklore in twenty-thirty years of the last century. Unfortunately, the known repression wave of thirty seventh year was ended his scientific activity.

According to the character of the event and the process ceremonial folklore and labour songs are known. Ceremonial folklore includes seasonal ceremonies, ceremonies concerning different natural processes, everyday life ceremonies, weddings and funerals. Bayaties are one of the richest genres of Azerbaijan folklore. The usually reflect lyricalphilosophical feelings of a human being in short poetic form. For instance we may count lulling, petting, elegy, counting words, holavar(labour poems), vesfi-hal (praising), bayati-baglama, bayatideyishme(competition in ssaying bayati), bayatitapmaca(bayati-puzzles) and others as the forms of this genre. Bayati is the form of poem containing of four lines with seven syllables in each. The form of rhyme is as follows: a-a-b-a. Ginas (the form of rhyming) historically takes a large place in Turkish poetry, so we may come across with bayati samples with ginas, too. One of the forms of bayati is that the first line of which contains only rhyme. Such kind of bayati can generally be seen in Karkuk folklore. The first two lines in bayati are somewhat like entrance to the main meaning.

\section{References:}

1. Qurbanov AM (1963) Müasir Azərbaycan dilinin frazeologiyası. Bakı: V.İ.Lenin adına APİ-nin motbəəsi.

2. İsmayılov H, Quliyeva R (2004) Azərbaycan folkloru antologiyası. (Gəncəbasar folkloru), IX cild. Bak1, 2004.

3. (2003) Gəncə folkloru antologiyası, I cild Tərtib edəni R.Quliyeva, Gəncə, 2003.

4. İncil (1995) Tərcümə edəni Mirzə Xəzər. Bibliya Tərcümə İnstitutu, Stokholm.

5. Tusi N (1989) “Oxlaqi-Nasiri” Bak1 "Elm”, pp. 162-167.
6. Mərasimlər, adətlər, alqışlar (1993) Gənclik, pp.92.

7. Mirzə Şəfi Vazeh (1961) Nəğmələr. Bak1, Azərbaycan Uşaq və Gənclər Odəbiyyatı Noşriyyatı.

8. (2003) Gəncə folkloru antologiyası. I kitab. Gəncə.

9. Mirzə Şəfi Vazeh (2014) Q1zılgül ətirli nəğmələr. Gəncə, Elm.

10. (2008) Gəncə folkloru antologiyası II kitab. Goncə. 